Metal-Catalyzed Asymmetric

Synthesis and

Stereoselective

Reactions

\section{Key words}

\section{ruthenium}

\section{transfer} hydrogenation

tridentate $\mathbf{N}$-ligands
T. C. JOHNSON, W. G. TORRY, M. WILLS* (THE UNIVERSITY OF WARWICK, COVENTRY, UK) Application of Ruthenium Complexes of Triazole-Containing Tridentate Ligands to Asymmetric Transfer Hydrogenation of Ketones

Org. Lett. 2012, 14, 5230-5233.

\title{
Asymmetric Ruthenium-Catalyzed Transfer Hydrogenation of Ketones
}

Overall transformation:<smiles>[R][X]1cccc(C(C)=O)c1</smiles><smiles>[R]c1ccc([C@H](C)O)cc1</smiles>

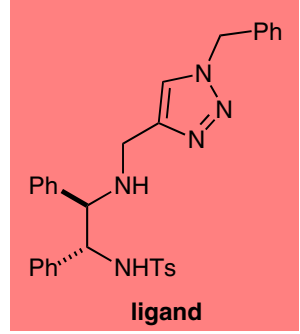

Selected substrate scope:<smiles>C[C@H](O)c1ccc(C(F)(F)F)cc1</smiles><smiles>COc1ccc([C@@H](C)O)cc1</smiles><smiles>Cc1cccc([C@H](C)O)c1</smiles><smiles>COc1ccccc1C(C)O</smiles><smiles>CC(O)c1ccccc1F</smiles>

$97 \%$ conv. $93 \%$ ee<smiles>C[C@H](O)c1ccccc1Br</smiles><smiles>O[C@H]1CCCc2ccccc21</smiles><smiles>OC1CCOc2ccccc21</smiles>

$99 \%$ conv $77 \%$ ee

$96 \%$ conv $91 \%$ ee
$98 \%$ conv.
$85 \%$ ee

$99 \%$ yield<smiles>C[C@H](O)c1ccccn1</smiles>

$52 \%$ conv. $67 \%$ ee
Significance: Transition-metal-catalyzed asymmetric transfer hydrogenation (ATH) has become a leading reduction method, which can be credited to its broad scope and relatively mild conditions. Additionally, the development of more general methods to synthesize chiral secondary alcohol is a useful endeavor. Specifically, the ATH reduction of ortho-substituted aryl ketones is considered a more challenging transformation than that of related meta- and para-substituted substrates.
Comment: The authors report a ruthenium-catalyzed ATH of substituted aryl methyl ketones using a novel tridentate triazole containing ligand. The scope of this transformation is quite broad, and conversions and enantioselectivities range from moderate to excellent. Notably, tetralone and 4chromanone can be reduced efficiently with synthetically useful enantioselectivity. The reduction of cyclohexyl methyl ketone proceeds with excellent conversion, yet enantioselectivity remains low (13\% ee). 